\title{
Are we wasting theology in our continent?
}

\begin{tabular}{|c|c|}
\hline \multicolumn{2}{|c|}{$\begin{array}{l}\text { Author: } \\
\text { H. Jurgens Hendriks }{ }^{1}\end{array}$} \\
\hline $\begin{array}{l}\text { Affiliation: } \\
{ }^{1} \text { Department } \\
\text { Theology and } \\
\text { Faculty of The } \\
\text { Stellenbosch } \\
\text { South Africa }\end{array}$ & $\begin{array}{l}\text { f Practical } \\
\text { Missiology, } \\
\text { ology, } \\
\text { Jniversity, }\end{array}$ \\
\hline $\begin{array}{l}\text { Note: } \\
\text { This article wa } \\
\text { a paper delive } \\
\text { Annual confer } \\
\text { Society for Pra } \\
\text { on } 23 \text { January } \\
\text { University of P } \\
\text { article address } \\
\text { of the confere } \\
\text { theology and } \mathrm{r} \\
\text { in Africa. }\end{array}$ & $\begin{array}{l}\text { s initially } \\
\text { red at the } \\
\text { ence of the } \\
\text { ctical Theology } \\
2014 \text { at the } \\
\text { retoria. The } \\
\text { ses the theme } \\
\text { nce: Practical } \\
\text { human waste }\end{array}$ \\
\hline $\begin{array}{l}\text { This article is } \\
\text { section Practic } \\
\text { of the Society } \\
\text { Theology in So }\end{array}$ & $\begin{array}{l}\text { oublished in the } \\
\text { al Theology } \\
\text { for Practical } \\
\text { uth Africa. }\end{array}$ \\
\hline $\begin{array}{l}\text { Corresponden } \\
\text { Jurgens Hendr }\end{array}$ & $\begin{array}{l}\text { Ice to: } \\
\text { iks }\end{array}$ \\
\hline $\begin{array}{l}\text { Email: } \\
\text { hjh@sun.ac.za }\end{array}$ & \\
\hline $\begin{array}{l}\text { Postal address } \\
\text { Faculty of The } \\
\text { Street } 171 \text {, Ste } \\
7600 \text {, South A }\end{array}$ & $\begin{array}{l}\text { ology, Dorp } \\
\text { ellenbosch } \\
\text { frica }\end{array}$ \\
\hline $\begin{array}{l}\text { Dates: } \\
\text { Received: } 24 \mathrm{~J} \\
\text { Accepted: } 28 \\
\text { Published: } 10\end{array}$ & $\begin{array}{l}\text { an. } 2014 \\
\text { May } 2014 \\
\text { Sept. } 2014\end{array}$ \\
\hline $\begin{array}{l}\text { How to cite th } \\
\text { Hendriks, H.J., } \\
\text { we wasting th } \\
\text { continent?', H } \\
\text { Studies/Theolc } \\
70(2) \text {, Art. \#26 } \\
\text { http://dx.doi.c } \\
\text { hts.v70i2.2610 }\end{array}$ & $\begin{array}{l}\text { is article: } \\
\text { 2014, 'Are } \\
\text { eology in our } \\
\text { TS Teologiese } \\
\text { gical Studies } \\
10,8 \text { pages. } \\
\text { rg/10.4102/ }\end{array}$ \\
\hline $\begin{array}{l}\text { Copyright: } \\
\text { (C) 2014. The A } \\
\text { Licensee: AOS } \\
\text { OpenJournals. } \\
\text { is licensed und } \\
\text { Creative Comn } \\
\text { Attribution Lic }\end{array}$ & $\begin{array}{l}\text { IS } \\
\text { IS } \\
\text { This work } \\
\text { der the } \\
\text { nons } \\
\text { ense. }\end{array}$ \\
\hline Read online: & $\begin{array}{l}\text { Scan this QR } \\
\text { code with your } \\
\text { smart phone or } \\
\text { mobile device } \\
\text { to read online. }\end{array}$ \\
\hline
\end{tabular}

The 2014 conference theme of the society for Practical Theology in South Africa was 'Practical Theology in Africa and human waste'. The article asks the question whether we can do theology in Africa in such a way that the kingdom of God is realised, notwithstanding the feeling that the seed that is sown is often wasted. The growth of Christianity and southern shift of the majority of Christians to amongst others Africa, is described, discussed and questioned: Is this seed falling on fertile ground or is it wasted if one considers all the calamities of the African continent? Taking its cues from the parable of the sower the epistemological revolution and paradigm shift are outlined stating that unless doing theology within a new paradigm the kingdom of God cannot be served. It calls for new paradigm labourers who are trained to be on the marketplace, who reach out to where people are suffering and struggling and serve their needs thus following the example set by Christ in training his disciples.

\section{Introduction}

Waste. The theme of the Society of Practical Theology is purposefully ambiguous. Juxtapositioning theology with waste calls for a myriad of reactions - especially on the African continent.

The parable of the sower deals with seed that is wasted in three out of four cases. In the fourth case there is a good return. We shall use the parable of the sower as a hermeneutical tool to examine the African scenario of doing theology. There are pointers in the parable that will help us to understand doing theology and the paradox of the growth of the church in our continent that is called in question by the many woes that the continent experiences.

We need to define the two central constructs used: waste and theology. The context and the audience to which the parable is addressed add perspective. Matthew (12:1-3) describes how Jesus talks to his disciples while they pluck and eat ears of grain on the Sabbath. The Pharisees confront them and insist that it is against the Law. The ensuing discussion in Matthew 13 happens against this background and, here, identity is a central theme (Bosch 1991:79-83). Mark seems to be more concerned with the large crowd and Jesus' teaching when he relates the parable (Mk 4:1, see Mk 3:7-11). Luke, like Matthew and Mark, mentions the large crowds that came from everywhere to hear Jesus, but Luke 8 starts by mentioning the women who follow Jesus. Jesus had healed some, whilst all of them served Jesus and his travelling disciples and 'provided for them out of their resources' (Lk 8:3).

The parable seems to portray a typical African scenario: large crowds wherever there is a service - be it in a mega church tabernacle in Nigeria, under a tree in Malawi, or in a large tent in South Africa. Women are always prominently present. In their colourful women's guild outfits, they are the real providers. But, and this is an important question that may serve us: Where does the 'seed' fall? How much is sown on paths, on the rocks, or are otherwise simply choked after conversion experiences. Wasted seed. And then there is seed that produces an abundant crop. When does this happen?

\section{Waste}

In the Merriam-Webster Dictionary (n.d.) the noun waste is described in several ways. Waste may refer to garbage, rubbish, scrap, desolation, emptiness, desolation. Whether used as a noun, a verb, or an adjective in combination with theology, waste helps us as it challenges us to examine the way we do theology. If we put it in the sower's context, it challenges us even more, because it confronts us with the results of our sowing and, as such, with the quality and understanding of theology. Where has the seed fallen? Are the harvest statistics available? And then: How do we understand theology and does our way of doing theology have any influence on the harvest statistics? 


\section{Where the seeds have fallen The growth of the church in Africa ${ }^{1}$}

'The Christian world's centre of gravity is shifting southwards to Africa, Asia and Latin America' (Hendriks 2013:1001). The World Christian Encyclopaedia (Barrett, Kurian \& Johnson 2001) as well as many other authorities (Cox 1995; Hendriks 2007; Jenkins 2002; Sanneh 2003; Walls 2002;) clarify this. In Table 1, 'South' represents Africa, South America and Oceania, whilst 'North' includes North America, Europe and Asia. The numbers are in millions.

Lamin Sanneh (2003:14-15, 18-19) points out that the growth of Christianity in Africa, compared to that of Islam, is remarkable (Box 1). After the departure of the missionaries, post-1962, Christian growth has accelerated remarkably (Box 2).

Figure 1a and Figure $1 \mathrm{~b}$ are from the South African Christian handbook 2005-2006 (Symington 2005:27-85). The religious scenario and trends in South Africa, based on the 1911-2001 census data are illustrated.

Figure 1a and Figure 1b overlap; Figure 1a depicts the mainline denominations that are all declining, whilst Figure $1 \mathrm{~b}$ depicts the African Independent Churches (AICs) and Pentecostal and Charismatic Churches that comprise approximately $70 \%$ of the black Christians. The denominations in Figure $1 \mathrm{~b}$ are all growing and expanding their market share. In 1911, only $25 \%$ of black South Africans were Christians. This percentage rose steadily to nearly $80 \%$ in 2001 - typifying the mission-evangelisation process that was taking place across Africa. A more detailed analysis reveals that a movement exists away from the mainline denominations towards the AICs, as well as towards the Pentecostal and Charismatic and new independent type of Christian Churches. The latter movement is visible in all population (racial) groups (Hendriks 2013:1003).

These tables illustrate the growth of the church in Africa. There is no doubt about the numerical growth of the church. The seed is indeed sown.

\section{Where the seed has fallen: What kind of soil?}

However, questions do arise. For instance: if the church has grown so spectacularly, and if the church is a 'stock of social capital for promoting social development' (Swart 2006:346), why is Africa in such a deplorable state when one examines issues such as the chronic wars, genocide, exploitation and

1.This section has been taken and adapted from Hendriks (2013:1001-1005) and at times includes verbatim quotes. violence against women and children, poverty, HIV / AIDS, corruption, and a chronic lack of reliable moral leadership, et cetera? (see Hendriks 2013:1005).

The Handbook for theological education in Africa (Phiri \& Werner 2013) presents two case studies that illustrate this point

BOX 1: Growth of the Christian Church in Africa.

- $1900-9$ million Christians $=9 \%$ of the population
- $1900-4$ Muslims for every 1 Christian
- $2005-411 \mathrm{~m}$ Christians $=46 \%$ of the population
- $2005-355 \mathrm{~m}$ Muslims $=40 \%$ of the population

Source: Adapted from Sanneh, L., 2003, Whose religion is Christianity? The Gospel beyond the West, Eerdmans, Grand Rapids

BOX 2: The post 1962 growth of the Church in Africa.

Independence came to Africa and missionaries started to leave.

1962 -60m Christians and 145m Muslims.

$2005-411 \mathrm{~m}$ Christians and 355m Muslims.

1970-1985 - Christianity grew by 16,500 conversions a day - mostly in poor areas. During the same time, 4300 people were leaving the church weekly in the West.

Source: Adapted from Sanneh, L., 2003, Whose religion is Christianity? The Gospel beyond the West, Eerdmans, Grand Rapids

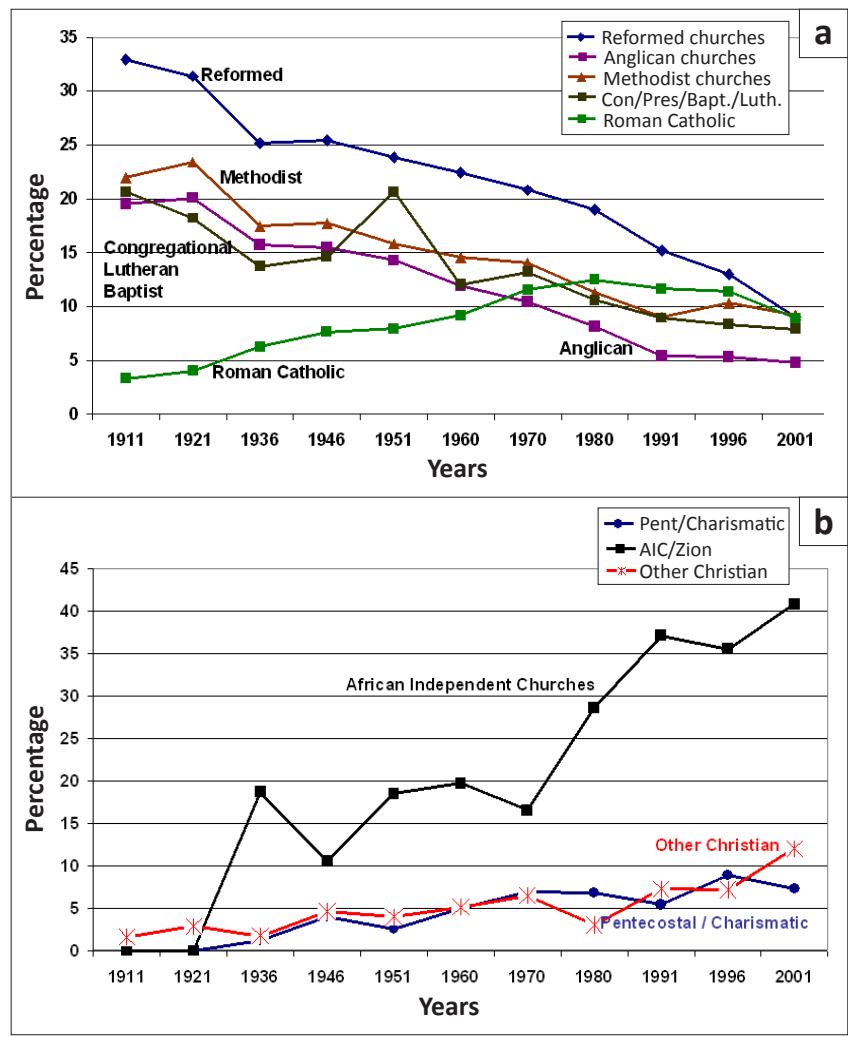

Source: Symington, J. (ed.), 2005, South African Christian handbook 2005-2006, Tydskriftemaatskappy, Wellington

FIGURE 1: (a) Christian market share mainline denomination 1911-2001 and (b) Christian market share: African Independent Churches, Pentecostal and other Christian: 1911-2001.

TABLE 1: The southern shift in Christianity.

\begin{tabular}{|c|c|c|c|c|c|c|}
\hline \multirow[t]{2}{*}{ Region } & \multicolumn{3}{|c|}{1900} & \multicolumn{3}{|c|}{2005} \\
\hline & Population & Christians & $\%$ Christians & Population & Christians & $\%$ Christians \\
\hline South & 179 & 73 & 41 & 1479 & 954 & 65 \\
\hline North & 1441 & 449 & 31 & 4975 & 1131 & 23 \\
\hline Total & 1620 & 522 & 32 & 6454 & 2085 & $32 \%$ \\
\hline
\end{tabular}

Source: Adapted from Hendriks, H.J., 2013, 'Reliable leadership, sustainable seminaries: The NetACT story 2000-2012', in I. Phiri \& D. Werner (eds.), Handbook for Theological Education in Africa, pp. 1001-1017, WCC-Cluster, Genève 
(Hendriks 2013:1003-1006). Onwunta's (2006, 2010) research is quoted to depict to what extent ethnocentrism has seriously influenced and eroded the growth of the Presbyterian Church in Nigeria. Nigerian's problems are on a daily basis reported in the media. Kagema's (2008 summarised in Hendriks 2013:1006-1008) research investigated the leadership training of the Anglican Church in Kenya. The paradoxical result is that this Church is growing at an astounding rate, but its theological training is permeated with tribalism, is not contextual and unable to deal with the social, political and economic challenges that the country faces. The Church is growing in numbers, but is losing ground in many ways, it does not seem to bring light nor act as salt.

Le Roux's (2012:49-60) Tearfund research in Burundi, Liberia, Rwanda and the Democratic Republic of the Congo focuses on the role of the church in dealing with sexual violence (SV) against women and children in areas affected by armed conflict. This is what she reports:

The 2010 and 2011 Tearfund fieldwork revealed a bleak picture of church involvement in dealing with sexual violence, both in a preventative sense and as a caring institution. All of the research sites emphasised that $\mathrm{SV}$ is a serious problem within their community and society, but that the churches in their communities (in general) fail to address it. In all the sites that formed part of the study, research participants told stories of churches that are not engaging with the issue; on the contrary, in many contexts churches were actively contributing to the stigma and discrimination which SV survivors face. ... It is not that they are unaware of the issue; on the contrary: 'Churches do know what is happening. But when it comes to doing something they are lethargic.' ... SV is like the proverbial elephant in the room; the church knows what is going on in the community, but pretends and attempts to be unaware of it. In doing this it takes its lead from the community. Communities refuse to address the issue. (Le Roux 2012:51-52)

The seed is seemingly wasted, as very little fruit is visible except the multitudes listening to the preachers, singing, and chanting as a way of putting their troubles aside. The point is that it seems as though very few seeds reach fertile soil. When there is a flurry of religious activities but it does not result in biblical moral values and sound ethical decisions, it questions the way theology is done. Is the way we do theology co-responsible for the waste?

\section{Theology \\ Cues from the Sower}

Theology is about understanding the Word spoken to you (Mt 13:13, 14, 23); it is about discovering and witnessing about Jesus Christ's musterion, the secret of the kingdom of God (Mt 13:11; Mk 4:11; Lk 8:10). One needs to hear and understand the Word that comes from the triune God, accept it (Mk 4:12, 20), and hold it fast in an honest, good heart in order that it may bear fruit through patient endurance (Lk 8:15). Understanding the Word of God is the secret of the kingdom. This 'understanding' is, however, more than mere intellectual consent. Bearing fruit is the proof of this understanding. Understanding implies obedience. It implies being intellectually and literally reborn in a new paradigm.
The Pharisees did not grasp this (Mt 12). The Law informed and dominated their paradigm. Thus, they were blind and were addressed in the form of parables. ${ }^{2}$

Compared with the Pharisees, Jesus did theology in a different paradigm. One's paradigm determines how you do theology, how you look and listen to the Word and the world. It also determines what happens to the seed.

In his case study of Mary, mother of Jesus, Steuernagel (2003:100-112) beautifully illustrates that theology comes during the second hour. Theology comprises words that are spoken in answer to God's presence and his Word. After hearing God's Word Mary answered (Lk 1:38): 'Here am I, the servant of the Lord; let it be with me according to your Word.' She struggled to discern what God meant. But once it was clear, when she understood, she accepted and she held fast to it, discussing it with Elizabeth and others. 'Her theology centred on God coming to her in, and through, Jesus Christ in the presence of the Holy Spirit' (Hendriks 2012:1). Theology is a 'womb thing,' it takes place in the deepest place where life is born (Steuernagel 2003:100); thus, it is a musterion that leads to rejoicing and worship. The Magnificat (Lk 1:46-55) is worship from the first Christian congregation ... where the majority of believers were women!

\section{The Word comes first. John 1 puts it like this:}

${ }^{1}$ In the beginning was the Word, and the Word was with God, and the Word was God. ${ }^{2} \mathrm{He}$ was in the beginning with God ... ${ }^{14}$ And the Word became flesh and lived among us, and we have seen his glory, the glory as of a father's only son, full of grace and truth.

Jesus is this Word. John explains this in various ways. In the parable of the sower, Jesus explains the reality that one faces when doing theology. A portion of the seed that falls on fertile soil bears fruit because it was understood, taken to heart, considered fully, believed, and lived. The musterion of Jesus Christ had been recognised, the kingdom of God was accepted and, as such, it adjusted the believers' lives. They recognised this new paradigm and accepted it. However, the same words can be wasted on paths, rocks and choked by weeds. Some go through the motions of theology but, similar to the Pharisees, they do not grasp the musterion, they neither recognise Jesus, nor follow and honour him, nor do they live according to the values of his kingdom. So, there is no blessing ( $\mathrm{Gn} \mathrm{12:1-3)} \mathrm{in} \mathrm{this} \mathrm{and} \mathrm{no} \mathrm{peace} \mathrm{can}$ follow (Lk 2:14); in other words, the seed was wasted.

One can illustrate the same phenomenon in Africa. ${ }^{3}$ The seed sown among the rocks resembles the prosperity cult

2.See Snodgrass (2008:145-177) for a detailed discussion of the parable and how Isaiah 6:9-10 is used in the parable. His concluding remarks (p. 176) are about the discrepancy between a good harvest and wasted seed: 'The parable is about hearing that leads to productive living, and adapting the parable will mean enabling people to move past merely hearing words - even with joy - to hearing that captures the whole person.'

3.There is ample evidence in the media and further on in this article to prove this point. Olo Ndukwe's discussion on 'Naming the disappointment' (2011:34-58) is a pood illustration of the word being wasted. So also Eme's chapters on 'Panorama good illustration of the word being wasted. So also Eme's chapters on 'Panorama of social problems in Nigeria' and 'The church in Nigeria today: social issues' (2012:39-69). Ogbu Kalu's study on Pentecostalism in Africa is an in-depth study of the topic (2008). On corruption the website of Transparency International (n.d.) is a must to consult on the topic. Their 'search by region (sub-Saharan Africa)' or 'search by country' compares to an opening of Pandora's box. 
and Pentecostal-charismatic cult-like services of rogue pastors. There is no depth. It 'chokes' the moment trouble or persecution sets in. The seeds sown among the thorns represent so many examples the cares of the world and the lure of wealth choke the Word' (Mt 13:22). Corruption kills the Word.

Jesus sends his disciples into the world with the good news of the kingdom of God, with his agenda for the world, the missio Dei. It is slightly more difficult to understand the tension and influences of doing theology today, even though, in its inner core, theology is about our reaction to the Word of God, the seed.

Thus, it is important to recap some of the story of theology in order to understand something about the reason why the church and its theological schools may be in a different paradigm. ${ }^{4}$ This article argues that we need a new hermeneutic for doing theology if we want the seed to fall in fertile ground.

\section{The epistemological revolution}

Andrew Walls (2002), the church historian, in his remarkable book, The cross-cultural process in Christian history, explained the paradigm shifts. The Christendom paradigm, which developed from the 4th century onwards, formed the Western worldview by creating a church-state division. As such, there was constant interaction between these spheres. To sketch the worst scenario, the Western world expected the church to look after the spiritual side of things, which of course is a personal matter, and to ensure that people go to heaven when they die. The state was responsible to care for the rest of the real world. The two worlds had different hermeneutical stances: the church used religious values and the state used facts. They were operating in two different realms (Bosch 1991:358-361). Phyllis Tickle (2008) explains how Christianity is changing and why. Reviewing the major 500-year cycles of thoughts and worldviews, and mapping the major fault lines and fusions, she helps us to understand the liminal space in which we are at present. Many young theologians at our theological institutions have been challenged to address the epochal paradigm shift and to explain it (Meylahn 2012b; also Macallan in the articles he wrote in collaboration with Hendriks [Macallan \& Hendriks 2012, 2013]).

We are wasting theology if we are unable to deal with these larger paradigmatic epistemological movements. Naming the major movements follows.

4. This is not a new debate. I have been greatly influenced by Farley (1983), Kelsey (1992), Keck (1993) and their ensuing debate. The ATLA Religion Database with ATLA Serials list 17 post-1993 articles under the heading "Between Athens and Berlin: The theological education debate." Locally, Conradie (1997:349-361) contrasted three models of teaching or doing theology, that is the Athens, Berlin and Calcutta models. This article says: look at the context and origin of the Christendom paradigm of the western world, look at the changing context, the influence of globalization and the information revolution and revisit key theological parameters in scripture. Observ what is happening in missional congregations and let all of these developments guide us on a journey to discover a new hermeneutic to do and teach theology (Hendriks 2012:1).
In the world of the natural sciences, Heisenberg's uncertainty principle, formulated in 1927, changed modernism's belief in rationality (Bell 2013:32-49; Wheatley 1999:36-37). ${ }^{5}$ In the words of two Nobel laureate physicists, quantum physics and the quantum theory became the most successful theory in the history of science (Bell 2013:42). Rationality is limited - it has boundaries and cannot provide any final answers to the miracles and mysteries of the universe. This shattered the presuppositions of the Enlightenment and modernism. In his book, What we talk about when we talk about God: Finding a new faith for the twenty-first century, Rob Bell (2013) discusses the implication of this cosmic epistemological shift. The way in which this book is written is, in itself, a paradigm shift in theological literature!

It took some time before the principle of uncertainty could influence the human sciences and especially theology. However, the work of Thomas Kuhn (1970) on The structure of scientific revolutions helped the social sciences to digest this epistemological shift. David Bosch (1991:349-367) and Lesslie Newbigin $(1989,1995)$ personally, helped me and many others to grasp this clearly and to follow the epistemological debate ever since. It also led to the epochal work of Wentzel van Huyssteen's (1997) Essays in postfoundationalist theology. Grenz and Franke (2001) observe:

In its broadest sense, foundationalism is merely the acknowledgment of the seemingly obvious observation that not all beliefs we hold (or assertions we formulate) are on the same level, but that some beliefs (or assertions) anchor others. Stated in the opposite manner, certain of our beliefs (or assertions) receive their support from other beliefs (or assertions) that are more 'basic' or 'foundational'. (p. 29)

There are only a few steps between foundationalism and fundamentalism. In due time, Theology developed a critical correlational hermeneutic that a working group of 30 African theologians applied to an African setting in their book on Practical Theology, Studying congregations in Africa (Hendriks 2004:23-34). The critical correlational hermeneutic is crucial in a post-foundationalist approach to Practical Theology and to Theology in general, as Van Huyssteen (1997; see also Meylahn 2006) argues:

In theological reflection then, a postmodern critique of foundationalist assumptions will therefore be an inextricable part of a post-foundationalist model of rationality, and will definitely shape the way in which theology is located within the context of interdisciplinary reflection. (p. 13)

Thus, the well-known dogma about the inerrancy of the Bible and the 'immutable laws and infallible truths' (Hanson 1986:535) were no longer acceptable. It put theology in all sorts of predicaments and embarrassments; for example, dogmatism is in disrepute. It became clear that a nonfoundationalist approach to scripture needs humility, needs to be done ecumenically, have coherency and should

5. Use a search engine and discover the many pages of internet references (MerriamWebster n.d.; Wikipedia n.d.b 'Uncertainty principle'). 
be handled with critical realism (Macallan \& Hendriks 2013:148-152). ${ }^{6}$

To conclude this subsection, two very important implications should be pointed out for the way in which we do theology and, as such, distinguish between wasting theology and doing theology responsibly. The first of these is that the essence of theology, as described in the section 'Cues from the sower' above, becomes viable once again. Theology done in a foundationalist way remains within a rational framework and eventually forces the theologian into a fundamentalistic straightjacket. It makes it extremely difficult to discern the Word. Interpreted within such a paradigm sola scriptura can, as Tickle illustrates (2008:145-165), replace the Pope as the final authority. The question remains: Whose interpretation of scripture is the most foundational, especially when they are in conflict?

This is not good soil for the seed, because ideological thorns usually choke the Word.Where does the 'uncertainty principle' leave theology? With relativism?

In the non-foundational sphere, there is less tension about relativism, as an earthbound Mr God who knows all the answers Pharisee-style is no longer around. The result is less arrogance and more humility when sowing. The challenge of discernment in doing theology is becoming a discipline in its own right (Hendriks 2004:30-32). One is reminded of Paul's words in 1 Corinthians 13 which, in a very real sense, echo the principle of uncertainty. ${ }^{7}$ The uncertainty applies to our humanness and our inability to ever fully comprehend the wonder and mystery of God and creation. ${ }^{8}$ We sow, only God can make the seed to grow.

\section{Transformation parameters}

In the parable of the sower, the seed is the Word. John helps us to find our vocation in the new paradigm of doing theology when he explains how the Word functioned:

John 1: ${ }^{14}$ And the Word became flesh and lived among us, and we have seen his glory, the glory as of a father's only son, full of grace and truth ... ${ }^{17}$ The Law indeed was given through Moses; grace and truth came through Jesus Christ. John 16: ${ }^{13}$ When the Spirit of truth comes, he will guide you into all the truth; for he will not speak on his own, but will speak whatever he hears, and he will declare to you the things that are to come.

6.Meylahn (2010:1) made most interesting suggestions on how to approach a postfoundational Practical Theology in Africa: 'Poetically Africa dwells: A dialogue between Heidegger's understanding of language as the house of being and African being-with (ubuntu) as a possible paradigm for postfoundational practical theology in Africa.'

7. ${ }^{\circ}$ Love never ends. But, as for prophecies, they will come to an end; as for tongues, they will cease; as for knowledge, it will come to an end. ${ }^{9}$ For we know only in part and we prophesy only in part; ${ }^{10}$ but when the complete comes, the partial will come to an end. ${ }^{11}$ When I was a child, I spoke like a child, I thought like a child, I reasoned like a child; when I became an adult, I put an end to childish ways. ${ }^{12}$ For now we see in a mirror, dimly (or in a riddle) but then we will see face to face. Now I know see in a mirror, dimly (or in a riddle) but then we will see face to face. Now I know hope, and love abide, these three; and the greatest of these is love (author's italics).

8.A wonderful philosophical article that explains this position is that of Meylahn (2012b:1): 'The folly of vulnerability beyond epistemic injustice and the power of knowledge: A vulnerable praxis of thinking (practical theological ethos) in globa conversation.
The Word lives in the power of the Spirit of truth among us and can make the seed to grow. We should ask ourselves how this happens. Taking stock of the changes that have taken place, the following are some hermeneutic parameters that could guide us:

- Do theology holistically and in the world. The Christendom paradigm is drawing to an end. The secular world and governments no longer acknowledge a churchstate relationship. The previous operational realms are no longer part of our worldview. In a sense, like most African cultures, we can view the world in which we live holistically. Religion can once again make a contribution on the public square (Ndukwe 2011).

- Theology done with an individualistic rational hermeneutic failed. Descartes's cogito ergo sum is widely recognised as the Enlightenment's kingpin thought and, ultimately, modernism (Bosch 1991:349). 'I think, therefore I am' is based on two presuppositions that are translatable to individualism and rationalism. This stance eventually led to foundationalism (Thiel 1994:3). As such, this is out of sync with passages like 1 Corinthians 13, John 1 and 16 (above). In theology, the Bible, scripture and confessions are often used in a rational way, as tools within a foundationalist and fundamentalistic paradigm that leaves no room for our fallibility and, ultimately, for God to be heard. This is sowing on rocky ground, wasting theology.

- The new epistemology that developed ever since Heisenberg's (cited in Wheatley 1999:36-37) uncertainty principle became accepted, led to what is called critical realism. Van Huyssteen (1997) explains:

- Personally I am convinced that no theologian who is trying to determine what the authority of the Bible might mean today, and to identify the epistemological status of the Bible in theological reflection, can avoid the important issues raised by some qualified forms of critical realism for theology. (p. 129)

- N.T. Wright (1992:32) agrees. It steers us between literalism and fictionalism while, simultaneously acknowledging that God can use the seed of the Word to bring forth fruit. Scripture's reliability is not at stake (Ganzevoort 2006:56). We are arriving at a place where we can do theology, meaning that we can hear the Word and, through the discipline of discernment, answer to what we believe God tells us, and acknowledging simultaneously that we are human and fallible.

- We should move beyond the encyclopaedic paradigm that has divided theology into a number of sub-disciplines, which were then also divided into different fields. Osmer (2008:235-241) points in this direction and summarises the historical events that led to the shredding of theology in the scientific paradigm where analysis was taken to extremes. It disempowered theologians, pastors and the church to deal with issues in a holistic way and led to all sorts of dilemmas and is wasting theology!

- In 2001 a group of African theologians acknowledged that theology is one discipline and we should do 
theology in congregations. If theology is done in congregations, it is contextual and empowers the faith community (i.e. 'ordinary' Christians) to make the right ethical choices (Hendriks 2004:14-16, 20). We waste theology when we claim that it is only an academic process where well-qualified subjects analyse an objective reality. Theology should be a discernment process that takes place as we follow Christ in this world and are confronted with choices and challenges that need answers. We see this in the setting of the parable of the sower.

- Doing theology is about being on a journey with Jesus. The goal is the coming of his kingdom. This journey should take us to places where we cross boundaries and face new realities. Ask the disciples, Mary, and the other women who followed Jesus, what this entails. We need to discover journeying anew. This soil may yield a bountiful harvest.

- David Bosch (1991:386) called this journey 'the emerging missionary paradigm.' It hardly needs any convincing that his words were prophetic. The missional movement has grown over the years. At its October 2013 meeting, the General Synod of the Dutch Reformed Church has redefined the identity and mission of the Church according to the principles of a missional church whose agenda seeks to follow the missio Dei. ${ }^{9}$ Reading from the section in Bosch (1991:368ff.), the terminology leaves no uncertainty of a new paradigm totally different from that of Christendom's mind-set.

To conclude this section, the paradigmatic shifts that took place put us in a situation where theology is unshackled from Christendom with its restricted agenda and scope. The Word was liberated to become flesh. If we cross boundaries, as Walls (2002) illustrated, the church will flourish. Then, the seed is not wasted.

What does this entails in a practical way?

\section{On the marketplace with others}

My experience is that post-foundational Christians, actually all non-fundamentalist religious people, are welcomed in public spaces, because people realise that, without them, the new globalising world cannot responsibly address the moral challenges that confront creation.

We are in a position where we have to do theology with others. Theology needs to be done cross-disciplinarily or trans-disciplinarily in a transversal approach. In a very real sense, the arguments outlined so far made it clear that theology is wasted if not done on the boundaries, with the poor and wherever there are real problems in the world. ${ }^{10}$ That is what Jesus with his disciples, did.

9.Nederduitse Gereformeerde Kerk (NGK) A.12.7 Raamwerkdokument oor die missionale aard en roeping van die NG Kerk.

10.There is ample literature that deals with the importance of and content of public theology. Visit the website of the Beyers Naude Centre for Public Theology (http:// www.beyersnaudecentre.org/) to see the activity and publications in this regard. Simply Google 'International journal for public theology' and find pages and pages of full text articles from this journal dealing with public theology.
I will illustrate this by referring to one of the leaders in the field of transformational change, Otto Scharmer (Wikipedia n.d.a). ${ }^{11}$ An Internet summary of Scharmer's (2013) publication reads:

We live in an age of profound disruption. Global crises, such as finance, food, fuel, water, resource scarcity and poverty, challenge just about every aspect of society. Yet, this disruption also brings the possibility of profound personal, societal and global renewal. We need to stop and ask: Why do we collectively create results nobody wants? What keeps us locked into the old ways of operating? And what can we do to transform these root issues that keep us trapped in the patterns of the past?

To work within the Enlightenment-modernism paradigm is to waste energy. It will not offer solutions. Einstein is quoted regularly in transformational leadership literature: 'We cannot solve problems with the same kind of thinking that created them' (Scharmer 2013:11). In other words, to do theology, and be church in the mould of the previous paradigm is a waste of the Sower's seed! This applies in a very real sense to our continent.

The MIT think-tank, as well as critical and responsible leaders worldwide, agree that the root cause of the problems that the world faces lies 'in our outdated paradigms of economic thought' (Scharmer 2013). We are approaching a moment of disruption. This article cannot give a summary of Scharmer's book and thoughts. However, in the circle of these global thinkers from all disciplines, the church and religious thinkers that operate within the new paradigm are welcomed and seen as essential partners.

This think-tank of 'secular' leadership summarises the symptoms of the current crisis 'in terms of three divides that disconnect self from the primary sources of life: ecological, social and spiritual' (Scharmer 2013). The first divide disconnects the self from nature, the second from 'the other' and the third from itself. It is truly tempting to go into detail about how this manifests globally and to disclose the shocking, astonishing statistics that underline these divides. However, the following quote will ring a number of bells that theologians will appreciate:

The blind spot of modern economic thought can be summarized with a single word: consciousness. Consciousness doesn't register as a category of economic thought. It happens to be a blind spot. However, in the reality of business leadership, the real role of a CEO has everything to do with it. For example, most work of managing change boils down to helping conflicting stakeholder

11.Dr. C. Otto Scharmer is a Senior Lecturer at the Massachusetts Institute of Technology (MIT) and the founding chair of the Presencing Institute. He chairs the MIT IDEAS program and helps groups of diverse stakeholders from business, government, and civil society to innovate at the level of the whole system... He has worked with governments in Africa, Asia, and Europe and has delivered awardwinning leadership and innovation programs for companies, including Daimler, Eileen Fisher, PriceWaterhouse, Fujitsu, Google, and Natura. He also is a Vice-Chair of the World Economic Forum's Global Agenda Council on New Leadership Models. Scharmer introduced the concept of "presencing" - learning from the emergin future - in his bestselling book Theory $U$ and Presence (the latter co-authored future - in his bestselling book Theory $U$ and Presence (the latter co-authored with P. Senge, J. Jaworski and B.S. Flowers), that has been translated into 15 languages' (Wikipedia n.d.a 'Otto Scharmer'). 'Scharmer introduced the concept of 'presencing' - learning from the emerging future - in his bestselling books Theory U and Presence (2005, the latter co-authored with P. Senge, J. Jaworski, and B.S. Flowers), which have been translated into fifteen languages' (Evolutionary Collective 2013). His best known publications are: Scharmer (2009) and Scharmer and Kaufer (2013). 
systems to move from one way of operating to another, that is, from just seeing their own point of view to seeing the problem from multiple perspectives. Whenever people leave their own points of view and begin to appreciate the perspectives of other stakeholders as well, the consequence will be better collaborative relationships and better results. (Scharmer 2013)

Theologians need to be in the market place, not only to observe the problems we face from multiple perspectives, but to contribute a perspective, to listen and discern, to raise their own level of consciousness and understanding in order to do theology! This is an absolute essential boundary to cross if ever the seeds are to reach fertile ground. God can only speak to us - we can only discern - when we have crossed a boundary and are conscious of 'the other side'.

To prove the applicability of this new venture and to indicate how well the soil has been prepared for a theological contribution, note the following key leadership challenge:

In other words, the economic imperatives of our time call for an evolution of our self from ego to eco, from one state of awareness to another. This is not just for moral reasons, but also for economic reasons because getting stuck in the state of the ego no longer makes for good business. ... Helping stakeholder systems to shift their way of operating from ego- to eco-system awareness is 'central' not only in the sense that it is shared across systems, but also in that the well-being and survival of our children and future generations depends on our ability to develop such collective capacities now. (Scharmer 2013)

Scharmer's (2013) book starts with this open invitation:

We have written this book for change-makers in all sectors, cultures, and systems, including business, government, civil society, media, academia and local communities.

Descartes's ego got theology into a lot of trouble. Going eco has a much better backing!

\section{In conclusion \\ Look for new paradigm labourers}

We should not be too self-assured about the church's Southern shift. There is enough statistical evidence that the church has grown most dramatically in Africa since the 1900s and especially after 1962. However, a look at the fruit of the seed should be a cause for concern. By most measures, our continent is in a terrible situation.

We need to do some soul-searching introspection of how we understand and do theology. Theology is done in the presence of Christ - that is, on the road, in the marketplace, whilst crossing boundaries. The Einstein-inspired question is whether we can solve the acute continental and global problem if we do theology according to a model developed in the Enlightenment-modernity paradigm that stood in the shadow of Christendom's worldview. The answer is an emphatic 'No!'

If done in an outdated paradigm, theology will not solve our problems and the seed will be wasted. My hypothesis is that theology in Africa is now challenged to provide leadership in the crossing of both the paradigmatic boundary of how theology is done and in moving from the rich to the poor world. It is a tremendous challenge, but our time has come to heed the call to make disciples - Matthew 28 and the parallel passages are challenging us once more.

Where do we start? I think the first step is to realise that we need to reach out and learn from 'the other,' who will have many configurations in Africa. A first step will be to include women in all deliberations. The single biggest challenge will be to relinquish institutional and professional power. To become humble and go out to serve our communities where it hurts, will be a necessary starting point. This was what Jesus did. It simply is a completely new ballgame. The answers will not come from conferences and the top - they need to be born in a manger ... out there.

We, who call ourselves theologians, need to be the midwives; we need to be available and, like Mary, allow Jesus to be born in us so that he can lead us. This calls for a journey out into the world.

\section{Acknowledgements Competing interests}

The author declares that he has no financial or personal relationship(s) that may have inappropriately influenced him in writing this article.

\section{References}

Barrett, D.T., Kurian, G.T. \& Johnson, T.M., 2001, World Christian Encyclopedia. A comparative survey of churches and religions in the modern world, vol. 1 2nd edn., Oxford University Press, Oxford.

Bell, R., 2013, What we talk about when we talk about God: Finding a new faith for the twenty-first century, Harper Collins, London.

Bosch, D., 1991, Transforming mission, Orbis, New York.

Conradie, E.M., 1997, 'An ABC in theological education?' Dutch Reformed Theological Journal 38(4), 349-361.

Cox, H., 1995, Fire from heaven: The rise of Pentecostal spirituality and the reshaping of religion in the twenty-first century, Addison-Wesley, New York.

Eme, K.U., 2012, The church in the society; mediating reforms through social communication, Tidyhouse, Aba, Nigeria.

Evolutionary Collective, 2013, Conversations 12 February 2013, viewed 21 July 2014, from http://evolutionarycollective.com/conversation/theory-u-leading-from-thefuture-as-it-emerges/

Farley, E., 1983, Theologia: The fragmentation and unity of theological education, Fortress Press, Philadelphia.

Ganzevoort, R.R., 2006, 'The social construction of revelation', International Journal of Practical Theology 8(2), 1-14. http://dx.doi.org/10.1515/IJPT.2006.003

Grenz, S.J. \& Franke, J.R., 2001, Beyond foundationalism: Shaping theology in a postmodern context, Westminster, Louisville.

Hanson, P.D., 1986, The people called: The growth of community in the Bible, Harper \& Row, San Francisco.

Hendriks, H.J., 2004, Studying congregations in Africa, Lux Verbi, Wellington.

Hendriks, H.J., 2007, 'Evangelism in Africa', Practical Theology in South Africa 22(1), 23-40.

Hendriks, H.J., 2012, 'Contextualizing theological education in Africa by doing theology in a missional hermeneutic', Koers - Bulletin for Christian Scholarship 77(2), 8 pages. http://dx.doi.org/10.4102/koers.v77i2.56

Hendriks, H.J., 2013, 'Reliable leadership, sustainable seminaries: The NetACT story 2000-2012', in I. Phiri \& D. Werner (eds.), Handbook for Theological Education in Africa, pp. 1001-1017, WCC-Cluster, Genève.

Jenkins, P., 2002, The next Christendom: The coming of global Christianity, Oxford University Press, Oxford. http://dx.doi.org/10.1093/0195146166.001.0001

Kalu, O.U., 2008, African Pentecostalism: An introduction, Oxford, Cape Town.

Keck, L.E., 1993, The Church confident, Abingdon, Nashville. 
Kelsey, D.H., 1992, To understand God truly: What's theological about a theological school, Westminster/John Knox Press, Louisville.

Kuhn, T.S., 1970, The structure of scientific revolutions, 2nd enlarged edn., University of Chicago, Chicago.

Le Roux, E., 2012, 'Why sexual violence? The social reality of an absent church', in H.J. Hendriks, E. Mouton, L. Hansen \& E. le Roux (eds.), Men in the pulpit, women in the pew? Addressing gender inequality in Africa, pp. 49-60, SUN Press, Stellenbosch

Macallan, B. \& Hendriks, H.J., 2012, 'A post-foundational Practical Theology? The pastoral cycle and local theology', Dutch Reformed Theological Journal 53(3/4), 193-204.

Macallan, B. \& Hendriks, H.J., 2013, 'Post-foundational Practical Theology as correlational hermeneutic', Acta Theologia 33(1), 135-157. http://dx.doi. org/10.4314/actat.v33i1.7ISSN 1015-8758

Merrian-Webster Dictionary, n.d., Uncertainty principle, viewed 03 October 2013, from http://www.merriam-webster.com/dictionary/uncertainty\%20principle

Meylahn, J-A., 2006, 'Postfoundationalism, deconstruction and the hope that motivates research in Practical Theology', HTS Teologiese Studies/Theological Studies 63(2), 983-999. http://dx.doi.org10.4102/hts.v62i3.385

Meylahn, J-A., 2010, 'Poetically Africa dwells: A dialogue between Heidegger's understanding of language as the house of being and African being-with (ubuntu) as a possible paradigm for postfoundational Practical Theology in Africa', Verbum et Ecclesia 31(1), Art. \#381, 9 pages. http://dx.doi.org10.4102/ve.v31i1.381

Meylahn, J-A., 2012a, Church emerging from the cracks: A church IN, but not OF the world, SUN Press, Stellenbosch.

Meylahn, J-A., 2012b, 'The folly of vulnerability beyond epistemic injustice and the power of knowledge: A vulnerable praxis of thinking (practical theological ethos) in global conversation', HTS Teologiese Studies/Theological Studies 68(2), Art $\# 1304,5$ pages. http://dx.doi.org/10.4102/hts.v68i2.1304

Ndukwe, O, 2011, Among the nations: rebranding the Christian church for a disappointed world, Preciousgrace, Nigeria.

Nederduitse Gereformeerde Kerk (NGK), Algemene Sinode, 2013, 'A.12.7 Raamwerkdokument oor die missionale aard en roeping van die kerk', besigtig Raamwerkdokument oor die missionale aard en roeping van die kerk', besigtig 01 November 2013, by http://wwW.as2013.co.za/wp-content/uploads/ agenda/A.12.7\%20MIS

Newbigin, L., 1989, The Gospel in a pluralist society, Eerdmans, Grand Rapids.

Newbigin, L., 1995, Proper confidence, faith, doubt and certainty in Christian discipleship, Eerdmans, Grand Rapids.

Onwunta, U.A., 2006, 'Ethnicity and missional strategies within the Presbyterian Church of Nigeria', doctoral thesis, Department of Practical Theology and Missiology, Stellenbosch University. http://scholar.sun.ac.za/handle/10019.1/17328

Onwunta, U.A., 2010, Ethnicity and the mission of the church in Nigeria: A Presbyterian perspective, Josany Press, Elelenwo.
Osmer, R.R., 2008, Practical Theology: An introduction, Eerdmans, Grand Rapids.

Phiri, I. \& Werner, D. (eds.), 2013, Handbook for theological education in Africa, WCC-Cluster, Genève.

Sanneh, L., 2003, Whose religion is Christianity? The Gospel beyond the West, Eerdmans, Grand Rapids.

Scharmer, C.O., 2009, Theory U: Leading from the future as it emerges: The social technology of presencing, Berret-Koehler, San Francisco.

Scharmer, O., 2013, 10 insights on the Ego-2-Eco economy revolution, viewed 01 October 2013, from http://www.blog.ottoscharmer.com/?p=557

Scharmer, C.O., Senge, P., Jaworski, J., Flowers, B.S., 2005, Presence: An exploration of profound change in people, organizations, and society, Doubleday, New York.

Scharmer, O. \& Kaufer, K., 2013, Leading from the emerging future: From ego-system to eco-system economies, Berrett-Koehler, San Francisco.

Snodgrass, K.R., 2008, Stories with intent: A comprehensive guide to the parables of Jesus, Eerdmans, Grand Rapids.

Steuernagel, V.R., 2003, 'Doing theology with an eye on Mary', Evangelical Review of Theology 27(2), 100-112.

Swart, I., 2006, 'Churches as a stock of social capital for promoting social development in Western Cape communities', Journal of Religion in Africa 36(3/4), 346-378. http://dx.doi.org/10.1163/157006606778941913

Symington, J. (ed.), 2005, South African Christian Handbook 2005-2006, Tydskriftemaatskappy, Wellington.

Thiel, J.E., 1994, Nonfoundationalism: Guides to theological enquiry, Fortress, Minneapolis.

Tickle, P., 2008, The great emergence: How Christianity is changing and why, Baker, Grand Rapids.

Transparency International, n.d., Corruption perspectives index, viewed 21 July 2014, from http://www.transparency.org/research/cpi/overview

Van Huyssteen, W., 1997, Essays in postfoundationalist theology, Eerdmans, Grand Rapids.

Walls, A.F., 2002, The cross-cultural process in Christian history, Orbis, Maryknoll.

Wheatley, M.J., 1999, Leadership and the new science, rev. \& expanded, BerrettKoehler, San Francisco.

Wikipedia, the Free Encyclopedia, n.d.a, s.v. Otto Scharmer, viewed 09 October 2013 from http://en.wikipedia.org/wiki/Otto_Scharmer

Wikipedia, the Free Encyclopedia, n.d.b, s.v. Uncertainty principle, viewed 03 October 2013, from http://en.wikipedia.org/wiki/Uncertainty_principle

Wright, N.T., 1992, The New Testament and the people of God, Fortress Press, Minneapolis. 